\title{
SITE-SPECIFIC PHOSPHORUS MANAGEMENT WITH INORGANIC FERTILIZER AND MUNICIPAL SOLID WASTE COMPOSTAPPLICATION IN SALT AFFECTED SOIL
}

\author{
S.M. Mehdi ${ }^{1}$, M. Sarfraz ${ }^{2, *}$, M.A. Qureshi ${ }^{3}$, M. Ilyas ${ }^{2}$, M.A. Zaka ${ }^{2}$, M.A. Qazi ${ }^{1}$ and H.U. Rafa ${ }^{1}$ \\ ${ }^{1}$ Soil Fertility Research Institute, Lahore, Pakistan; ${ }^{2}$ Soil Salinity Research Institute, Pindi Bhattian, Pakistan; \\ ${ }^{3}$ Agri. Biotechnology Research Institute, AARI, Faisalabad, Pakistan. \\ "Corresponding author's e-mail: sarfrazpnd@gmail.com
}

\begin{abstract}
Salt affected soils either developed from parent material (primary) or from anthropogenic activities (secondary) extended in arid and semi-arid regions reduced the crop growth. An increasing trend of salt affected soils is a major risk for food security and sustainable agriculture. The adverse effect of salt stress on crop growth is related with the specific ion toxicity, low osmotic potential and nutritional imbalance. Salt stress damages the soil physical properties that can be improved by addition of organic amendments such as municipal solid waste compost (MSWC). MSWC is eco-friendly, adds organic matter in soil and compensate the mineral fertilizer. Field experiments were conducted to assess the site-specific nutrient management using MSWC in rice-wheat cropping system under salt affected conditions. Application of inorganic and organic content (MSWC) keeping in consideration the P-fixation capacity of soils and site-specific nutrient management approach can improve the crop yields. Results revealed that site-specific use of mineral fertilizer with MSWC and integrated use of chemical fertilizers with MSWC in 80:20 ratio improve the paddy/grain yield and soil health. Site-specific and integrated use of chemical fertilizer with MSWC in 80:20 ratio produced the highest biomass / paddy and biomass/grain yield i.e. 11.04/2.67 and 5.62/2.70 Mg ha ${ }^{-1}$ at Kot Murad, District Hafizabad, respectively. Pre-sowing and postharvest soils analysis was carried out after transplanting/sowing of each crop. Integrated and site specific use of MSWC slightly reduced the salinity/sodicity than the initial status of soil while organic matter, available $\mathrm{P}$, extractable $\mathrm{K}$ and $\mathrm{Zn}$ were increased compared to initial values.
\end{abstract}

Keywords: MSWC, site-specific P management, P-fixation factor, rice-wheat rotation

\section{INTRODUCTION}

Salt affected soils are distributed worldwide and considered a major threat to the semi-arid regions like Pakistan. Saltaffected soils are characterized by excessive soluble salts and dominance of $\mathrm{Na}^{+}$on exchange sites and main threat for sustainable agriculture causing reduction in yield of glycophytes (Hasegawa et al., 2000; Qadir et al., 2001; Sherani et al., 2017). The sodium $\left(\mathrm{Na}^{+}\right)$and chloride $\left(\mathrm{Cl}^{-}\right)$ions exerted osmotic stress and damaged the plants at cellular level (Mansour and Salama, 2000; Chinnusamy et al., 2005). Saltaffected soils of Pakistan are mostly saline-sodic/sodic where $\mathrm{Na}^{+}$as dispersion agent hampers the hydraulic properties and obstruct the conducting pores. The management of salt affected soils can be carried out by addition of chemical amendments followed by leaching that replaced $\mathrm{Na}^{+}$from the exchange sites and biological means (Sharma and Minhas, 2005; Qadir et al., 2007). Among the chemical amendments, gypsum is the most economical and reliable resource (Ghafoor et al., 2011). Application of organic content to salt affected soils is an effective approach for improving chemical, physical and biological properties of soils although response is slow. Addition of organic amendments like green manures, farmyard, poultry manures, crop residues, press mud and MSWC improve the plant growth and soil quality (Hanay et al., 2004; Sharma and Minhas, 2005; Tejada et al., 2006; Qazi et al., 2009; Wong et al., 2009).

Imbalance and insufficient availability of nutrients is characterized feature of salt affected soils. Pakistani soils, especially soils affected by salinity/sodicity are generally deficient in nitrogen and phosphorus (Arain et al., 2000). Soils have variable $\mathrm{P}$ fixation capacity depending upon many factors i.e. $\mathrm{pH}$ of the soil, organic matter, clay type and exchangeable cations. The $\mathrm{P}$ fixation capacity of soils have considerable relationship with $\mathrm{pH}$, exchangeable cations, clay content, soluble phosphate, amount of $\mathrm{P}$ fixed and salinity/sodicity constrain its availability to plants. Phosphorus dynamics in the soil and its fixation/released characteristic have relevancy with the amount of $\mathrm{P}$ available for growing crops from the native soil pool (Dibb, 1990; Glendinning, 1990). Phosphorus fixation capacity of soils is responsible for its poor availability and limits the plant growth. It was reported that $\sim 80 \%$ of added $\mathrm{P}$ fertilizers immobilized due to metal complexes (Schachtman et al., 1998). The metal complexes formed due to phosphate anions with $\mathrm{Ca}$ or $\mathrm{Mg}$ in calcareous soils and $\mathrm{Al}$ or $\mathrm{Fe}$ in acidic soils promotes the $\mathrm{P}$ fixation. Phosphorus use efficiency can be enhanced and losses of $\mathrm{P}$ can be reduced by site-specific 
application of $\mathrm{P}$ or on soil-need basis. Application of $\mathrm{P}$ on soil-need basis is the need of time for avoiding P losses and sustainable agriculture (McLean et al., 1982; Juang et al., 2002).

Salt-affected soils have disturbed soil structure and nutrient balance that can be improved by the application of organic matter. Organic matter improves the physical properties i.e. granulation, water holding capacity and chemical properties i.e. cation exchange capacity, adsorbing power of soils and promote the soil biology that is responsible for nutrient transformations and nutrients availability (Madejon et al., 2001; Brady and Weil, 2005; Melero et al., 2007). Organic amendment addition in salt affected soils promoted the hydraulic conductivity, water holding capacity and porosity of soil (Hussain et al., 2001) and enhanced leaching, infiltration rate, water-holding capacity, aggregate stability and reduced electrical conductivity and ESP (Qadir et al.,2001). Applications of organic sources after bioconversion of organic substances i.e. FYM, poultry manure, press mud, crop residues, sewage sludge and municipal solid waste in the form of compost improve soil fertility and supplement the inorganic fertilizers (Madejon et al., 2001; Melero et al., 2007). Application of MSWC in the fields not only protects our environment by diminishing the waste dumps and incineration but also provides nutrients and aggregate stability to the crop stand (Yaghmaeian et al., 2005; Alidadi et al., 2008; Tzortzakis et al., 2012). Addition of MSWC as an organic source promotes the leaching due to granulation and nutrient availability (Chun et al., 2007; Munns and Tester, 2008; Rajendran et al., 2009). Integrated nutrient management with MSWC in salt affected soils specifically for $\mathrm{P}$ application on soil need basis is better and more practical approach to acquire sustainability. Field studies at Kot Murad district Hafizabad were conducted to assess the approach of site-specific nutrient management using MSWC in rice-wheat cropping pattern under salt affected conditions.

\section{MATERIALS AND METHODS}

Site was selected at Kot Murad District Hafizabad and field was prepared. A permanent layout was designed for ricewheat rotation lasting for three years. Studies were laid out in randomized complete block design (RCBD). Initial soil status of the selected site is given in Table 1. After determination of $P$ fixation capacity of soil, the recommended standard test phosphorus (STP) target value of $16 \mathrm{mg} \mathrm{kg}^{-1}$ was maintained as described by McLean et al. (1982). The $\mathrm{P}$ fixation factor was determined and used as multiplier of differences to maintain the target sufficiency levels of $\mathrm{P}$ i.e. $16 \mathrm{mg} \mathrm{kg}^{-1}$ from mineral fertilizer and MSWC. The $\mathrm{P}$ fixation factor was calculated on the basis of $\mathrm{P}$ fixation capacity. The $\mathrm{P}$ fixation capacity was determined by taking $1.0 \mathrm{~g}$ soil, $0.5 \mathrm{~mL}$ of $\mathrm{KH}_{2} \mathrm{PO}_{4}$ solution of $60 \mathrm{mg} \mathrm{kg}{ }^{-1} \mathrm{P}$ and equilibrated for 2 hours. The reciprocal of fraction of $\mathrm{P}$ recovered from added was designated as $\mathrm{P}$ fixation factor $\left(\mathrm{F}_{\mathrm{p}}\right)$. The treatments are i) $\mathrm{T}_{1^{-}}$ Control, ii) $\mathrm{T}_{2}$ - Recommended sole use of chemical fertilizer, iii) $T_{3}-$ Site specific use of chemical fertilizer, iv) $T_{4}$ Integrated use of chemical fertilizer with MSWC in 80:20 ratio, v) $\mathrm{T}_{5}-$ Site specific integrated use of the chemical fertilizer and MSWC in 80:20 ratio. Recommended fertilizers applied to rice and wheat were 110-90-75 and 130-110-90 kg $\mathrm{ha}^{-1}$, respectively. MSWC was analyzed and the composition along with the permissible limits is given in Table 2. Analysis of MSWC used in these studies has total N: $0.47-0.63 \%$, total P: $0.33-0.38 \%$, total K: $1.02-1.15 \%, \mathrm{Zn}: 320-520, \mathrm{Cu}: 86-109$, Cd: 0-2.80, Co: 3.80-12.50 and Pb: 120-462 $\mathrm{mg} \mathrm{kg}^{-1}$ (Tandon, 2005).

Table 1. Initial soil status at Kot Murad.

\begin{tabular}{lccc}
\hline Parameters & Units & $\begin{array}{c}\text { Soil Depth } \\
(\mathbf{0 - 1 5} \text { cm })\end{array}$ & $\begin{array}{c}\text { Soil Depth } \\
(\mathbf{1 5 - 3 0} \text { cm })\end{array}$ \\
\hline Soil Texture & & Sandy Loam & Sandy Loam \\
Bulk density & $\left(\mathrm{Mg} \mathrm{m}^{-3}\right)$ & $1.60(10-15 \mathrm{~cm})$ & $1.58(20-25 \mathrm{~cm})$ \\
$\mathrm{pH}_{\mathrm{s}}$ & & 8.74 & 8.67 \\
EC & & 5.75 & 4.94 \\
$\mathrm{SAR}$ & $\left(\mathrm{dS} \mathrm{m}^{-1}\right)$ & 38.67 & 29.47 \\
Organic Matter & $(\%)$ & 0.40 & 0.34 \\
Available P & $\left(\mathrm{mg} \mathrm{kg} \mathrm{k}^{-1}\right)$ & 8.60 & 7.85 \\
Extractable K & $\left(\mathrm{mg} \mathrm{kg}^{-1}\right)$ & 117.33 & 100.42 \\
DTPA Extractable & & \\
Zn & $\left(\mathrm{mg} \mathrm{kg}^{-1}\right)$ & 0.80 & 0.48 \\
$\mathrm{Cu}$ & $\left(\mathrm{mg} \mathrm{kg}^{-1}\right)$ & 0.40 & 0.36 \\
$\mathrm{Co}$ & $\left(\mathrm{mg} \mathrm{kg}^{-1}\right)$ & 0.20 & 0.14 \\
$\mathrm{Cd}$ & $\left(\mathrm{mg} \mathrm{kg}^{-1}\right)$ & 0.20 & 0.18 \\
$\mathrm{~Pb}$ & $\left(\mathrm{mg} \mathrm{kg}^{-1}\right)$ & 0.60 & 0.28 \\
\hline
\end{tabular}

Table 2. Chemical composition of municipal solid waste compost.

\begin{tabular}{llcc}
\hline Determinations & Units & Value & Permissible limits \\
\hline Total $\mathrm{N}$ & $\%$ & $0.47-0.63$ & - \\
Total P & $\%$ & $0.33-0.38$ & - \\
Total K & $\%$ & $1.02-1.15$ & - \\
Total $\mathrm{Zn}$ & $\mathrm{mg} \mathrm{kg}^{-1}$ & $320-520$ & 7500 \\
Total $\mathrm{Cu}$ & $\mathrm{mg} \mathrm{kg}^{-1}$ & $86-109$ & 4300 \\
Total Cd & $\mathrm{mg} \mathrm{kg}^{-1}$ & $0-2.80$ & 85 \\
Total Co & $\mathrm{mg} \mathrm{kg}^{-1}$ & $3.80-12.50$ & - \\
Total $\mathrm{Pb}$ & $\mathrm{mg} \mathrm{kg}^{-1}$ & $120-462$ & 840 \\
\hline
\end{tabular}

*Standards for sewage sludge and domestic septage established by US Environmental Protection Agency (EPA) in 1995.

Yield parameters of rice and wheat like biomass and paddy yield / grain yield data were recorded at harvest. Pre-sowing and post-harvest soil samples were collected from 0-15 and 15-30 cm soil depths. Different parameters $\left(\mathrm{pH}_{\mathrm{s}}, \mathrm{EC}_{\mathrm{e}}, \mathrm{SAR}\right.$, O.M and extractable $\mathrm{K}$ ) were determined according to the methods described in US Salinity Lab. Staff (1954) and Tandon (2005). Soil bulk density was determined using core sampler from $10-15$ and $20-25 \mathrm{~cm}$ soil depths (Blake and 
Hartge, 1986) and soil texture was determined using hydrometer method (Bouyoucos, 1962) and available P was determined by modified Olsen method (Watanab and Olsen, 1965).DTPA extractable ( $\mathrm{Zn}, \mathrm{Cu}, \mathrm{Co}, \mathrm{Cd}$ and $\mathrm{Pb}$ ) were determined using the methods as described by Lindsay and Norvell (1978). Data were subjected to statistical analysis using standard procedures following RCBD (Steel et al., 1997). The differences among the means were compared by applying the Duncan's multiple range tests (Duncan, 1955).

\section{RESULTS AND DISCUSSION}

Three years experimentations were carried out with permanent layout in rice-wheat cropping system at Kot Murad district Hafizabad. Before start of the experiments, initial soil status showed that soil was sandy loam, bulk density: 1.60 and $1.58 \mathrm{Mg} \mathrm{m}^{-3}$ in $10-15 \mathrm{~cm}$ and $20-25 \mathrm{~cm}$ soil depth, respectively (Table 1 ). Soil analysis showed that soil was sandy loam, saline sodic with moderate available P status and low in organic matter content.
Data regarding biomass and paddy/grain yield of rice and wheat are presented in Table 3 . The results revealed that site specific integrated use of chemical fertilizer with MSWC in 80:20 ratio produced significantly higher biomass and paddy yield (11.04 and $2.67 \mathrm{Mg} \mathrm{ha}^{-1}$ ) followed by integrated use of chemical fertilizers with MSWC in 80:20 ratio) i.e. 10.02 and $2.48 \mathrm{Mg} \mathrm{ha}^{-1}$, respectively. Site specific use of chemical fertilizers produced higher biomass and paddy yield (9.46 and $2.30 \mathrm{Mg} \mathrm{ha}^{-1}$ ) than recommended sole use of chemical fertilizers (9.00 and $2.19 \mathrm{Mg} \mathrm{ha}^{-1}$ ) and lowest with control (3.89 and $0.96 \mathrm{Mg} \mathrm{ha}^{-1}$ ).

Site specific integrated use of chemical fertilizer with MSWC in 80:20 ratio produced highest biomass and grain yield of wheat as well i.e. 5.62 and $2.70 \mathrm{Mg} \mathrm{ha}^{-1}$ followed by integrated use of chemical fertilizers with MSWC in 80:20 ratio i.e. 5.12 and $2.61 \mathrm{Mg} \mathrm{ha}^{-1}$, respectively. Site specific use of chemical fertilizers produced higher biomass and grain yield i.e. 5.32 and 2.55 than recommended sole use of chemical fertilizers i.e. 5.06 and 2.41 compared to control i.e. 1.91 and $0.92 \mathrm{Mg} \mathrm{ha}^{-1}$, respectively (Table 3).

Table 3. Effect of integrated application of $P$ on biomass and paddy / grain yield of rice and wheat at Kot Murad.

\begin{tabular}{|c|c|c|c|c|}
\hline \multirow{3}{*}{ Treatments } & \multirow{2}{*}{\multicolumn{2}{|c|}{ Rice Yield (Mg ha $\left.{ }^{-1}\right)$}} & \multicolumn{2}{|c|}{ Average of three years) } \\
\hline & & & Wheat Yic & $\left.\operatorname{Mg~ha}^{-1}\right)$ \\
\hline & Biomass & Paddy & Biomass & Grain \\
\hline $\mathrm{T}_{1}$ - Control & $3.89 * \mathrm{E}$ & $0.96 \mathrm{E}$ & $1.91 \mathrm{C}$ & $0.92 \mathrm{D}$ \\
\hline $\mathrm{T}_{2}$ - Recommended sole use of chemical fertilizers & $9.00 \mathrm{D}$ & $2.19 \mathrm{D}$ & $5.06 \mathrm{~B}$ & $2.41 \mathrm{C}$ \\
\hline $\mathrm{T}_{3}$-Site specific use of chemical fertilizers & $9.46 \mathrm{C}$ & $2.30 \mathrm{C}$ & $5.32 \mathrm{AB}$ & $2.55 \mathrm{~B}$ \\
\hline $\mathrm{T}_{4}$ - Integrated use of chemical fertilizers with MSWC in $80: 20$ ratio & $10.02 \mathrm{~B}$ & $2.48 \mathrm{~B}$ & $5.12 \mathrm{AB}$ & $2.61 \mathrm{AB}$ \\
\hline $\begin{array}{l}\mathrm{T}_{5} \text {-Site specific integrated use of chemical fertilizer with MSWC in } \\
80: 20 \text { ratio }\end{array}$ & $11.04 \mathrm{~A}$ & $2.67 \mathrm{~A}$ & $5.62 \mathrm{~A}$ & $2.70 \mathrm{~A}$ \\
\hline LSD & 0.361 & 0.087 & 0.565 & 0.124 \\
\hline
\end{tabular}

*Means sharing the same letter(s) in a column do not differ significantly at $\mathrm{p}<0.05$ according to Duncan's Multiple Range Test.

Table 4. Soil analysis after rice harvest $(0-15$ and 15-30cm) at Kot Murad.

\begin{tabular}{|c|c|c|c|c|c|c|}
\hline \multirow{3}{*}{ Treatments } & & & & & Avel & of three years \\
\hline & $\mathbf{p H}_{\mathrm{s}}$ & 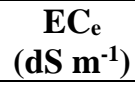 & $\begin{array}{c}\text { SAR } \\
\left(\mathrm{mmol} \mathrm{L}^{-1}\right)^{1 / 2} \\
\end{array}$ & $\begin{array}{c}\text { O.M. } \\
(\%)\end{array}$ & $\begin{array}{c}\text { Available P } \\
\left(\mathrm{mg} \mathrm{kg}^{-1}\right)\end{array}$ & $\begin{array}{c}\text { Extractable K } \\
\left(\mathrm{mg} \mathrm{kg} \mathrm{k}^{-1}\right) \\
\end{array}$ \\
\hline & \multicolumn{6}{|c|}{$(0-15 \mathrm{~cm})$} \\
\hline$\overline{\mathrm{T}_{1}}$ & $8.533 \mathrm{~A}$ & $4.13 \mathrm{~B}$ & $24.36 \mathrm{~A}$ & $0.277 \mathrm{~B}$ & $5.11 \mathrm{~B}$ & $87.26 \mathrm{~B}$ \\
\hline $\mathrm{T}_{2}$ & $8.517 \mathrm{~B}$ & $3.23 \mathrm{~B}$ & $22.49 \mathrm{~B}$ & $0.537 \mathrm{~A}$ & $13.15 \mathrm{~A}$ & $144.83 \mathrm{~A}$ \\
\hline $\mathrm{T}_{3}$ & $8.523 \mathrm{AB}$ & $3.22 \mathrm{~B}$ & $22.48 \mathrm{~B}$ & $0.550 \mathrm{~A}$ & $12.22 \mathrm{~A}$ & $144.10 \mathrm{~A}$ \\
\hline $\mathrm{T}_{4}$ & $8.500 \mathrm{C}$ & $3.19 \mathrm{~B}$ & $21.81 \mathrm{~B}$ & $0.620 \mathrm{~A}$ & $13.27 \mathrm{~A}$ & $148.81 \mathrm{~A}$ \\
\hline $\mathrm{T}_{5}$ & $8.500 \mathrm{C}$ & $3.15 \mathrm{~B}$ & $21.71 \mathrm{~B}$ & $0.610 \mathrm{~A}$ & $12.73 \mathrm{~A}$ & $148.25 \mathrm{~A}$ \\
\hline \multirow[t]{2}{*}{ LSD } & 0.015 & 0.194 & 1.426 & 0.132 & 4.125 & 23.576 \\
\hline & \multicolumn{6}{|c|}{$(15-30 \mathrm{~cm})$} \\
\hline $\mathrm{T}_{1}$ & $8.57 \mathrm{~A}$ & $4.24 \mathrm{~A}$ & $27.17 \mathrm{~A}$ & $0.217 \mathrm{~B}$ & $4.72 \mathrm{~B}$ & $83.41 \mathrm{~B}$ \\
\hline $\mathrm{T}_{2}$ & $8.55 \mathrm{BC}$ & $3.73 \mathrm{~B}$ & $24.26 \mathrm{~B}$ & $0.407 \mathrm{~A}$ & $8.76 \mathrm{~A}$ & $109.42 \mathrm{~A}$ \\
\hline $\mathrm{T}_{3}$ & $8.56 \mathrm{AB}$ & $3.69 \mathrm{~B}$ & $23.59 \mathrm{~B}$ & $0.413 \mathrm{~A}$ & $8.73 \mathrm{~A}$ & $109.81 \mathrm{~A}$ \\
\hline $\mathrm{T}_{4}$ & $8.54 \mathrm{CD}$ & $3.69 \mathrm{~B}$ & $23.60 \mathrm{~B}$ & $0.447 \mathrm{~A}$ & $9.04 \mathrm{~A}$ & $111.31 \mathrm{~A}$ \\
\hline $\mathrm{T}_{5}$ & $8.53 \mathrm{D}$ & $3.62 \mathrm{~B}$ & $24.09 \mathrm{~B}$ & $0.437 \mathrm{~A}$ & $8.99 \mathrm{~A}$ & $111.22 \mathrm{~A}$ \\
\hline LSD & 0.014 & 0.319 & 2.488 & 0.093 & 2.828 & 17.39 \\
\hline
\end{tabular}

*Means sharing the same letter(s) in a column do not differ significantly at $\mathrm{p}<0.05$ according to Duncan's Multiple Range Test. 
Table 5. Soil analysis after wheat harvest $(0-15$ and $15-30 \mathrm{~cm})$ at Kot Murad.

\begin{tabular}{|c|c|c|c|c|c|c|}
\hline \multirow[t]{2}{*}{ Treatments } & $\mathrm{pH}_{\mathrm{s}}$ & $\begin{array}{c}E C_{e} \\
\left(d S ~ m^{-1}\right)\end{array}$ & $\begin{array}{c}\text { SAR } \\
\left(\mathrm{mmol} \mathrm{L}^{-1}\right)^{1 / 2}\end{array}$ & $\begin{array}{l}\text { O.M. } \\
(\%)\end{array}$ & $\begin{array}{c}\text { Available P } \\
\left(\mathrm{mg} \mathrm{kg}^{-1}\right)\end{array}$ & $\begin{array}{c}\text { Extractable K } \\
\left(\mathrm{mg} \mathrm{kg}^{-1}\right)\end{array}$ \\
\hline & \multicolumn{6}{|c|}{$(0-15 \mathrm{~cm})$} \\
\hline $\mathrm{T}_{1}$ & 8.516 & $3.983 \mathrm{~A}$ & 22.62 & $0.243 \mathrm{~B}$ & $4.13 \mathrm{~B}$ & $81.87 \mathrm{~B}$ \\
\hline $\mathrm{T}_{2}$ & 8.497 & $3.163 \mathrm{~B}$ & 21.18 & $0.567 \mathrm{~A}$ & $13.98 \mathrm{~A}$ & $151.68 \mathrm{~A}$ \\
\hline $\mathrm{T}_{3}$ & 8.520 & $3.177 \mathrm{~B}$ & 21.90 & $0.573 \mathrm{~A}$ & $12.67 \mathrm{~A}$ & $150.48 \mathrm{~A}$ \\
\hline $\mathrm{T}_{4}$ & 8.507 & $3.147 \mathrm{~B}$ & 21.38 & $0.657 \mathrm{~A}$ & $14.29 \mathrm{~A}$ & $152.16 \mathrm{~A}$ \\
\hline $\mathrm{T}_{5}$ & 8.507 & 3.143 B & 21.35 & $0.633 \mathrm{~A}$ & $13.13 \mathrm{~A}$ & $152.52 \mathrm{~A}$ \\
\hline \multirow[t]{2}{*}{ LSD } & 0.024 & 0.081 & 8.654 & 0.124 & 3.756 & 18.52 \\
\hline & \multicolumn{6}{|c|}{$(15-30 \mathrm{~cm})$} \\
\hline $\mathrm{T}_{1}$ & $8.53 \mathrm{~A}$ & $4.10 \mathrm{~A}$ & $23.46 \mathrm{~A}$ & $0.183 \mathrm{~B}$ & $3.75 \mathrm{~B}$ & $79.07 \mathrm{~B}$ \\
\hline $\mathrm{T}_{2}$ & $8.51 \mathrm{~B}$ & $3.36 \mathrm{~B}$ & $21.97 \mathrm{~B}$ & $0.427 \mathrm{~A}$ & $8.93 \mathrm{~A}$ & $113.04 \mathrm{~A}$ \\
\hline $\mathrm{T}_{3}$ & $8.53 \mathrm{~A}$ & $3.34 \mathrm{~B}$ & $22.55 \mathrm{AB}$ & $0.430 \mathrm{~A}$ & $8.86 \mathrm{~A}$ & $113.30 \mathrm{~A}$ \\
\hline $\mathrm{T}_{4}$ & $8.52 \mathrm{AB}$ & $3.31 \mathrm{~B}$ & $21.88 \mathrm{~B}$ & $0.467 \mathrm{~A}$ & $9.24 \mathrm{~A}$ & $114.62 \mathrm{~A}$ \\
\hline $\mathrm{T}_{5}$ & $8.52 \mathrm{AB}$ & $3.32 \mathrm{~B}$ & $21.95 \mathrm{~B}$ & $0.443 \mathrm{~A}$ & $9.13 \mathrm{~A}$ & $113.65 \mathrm{~A}$ \\
\hline LSD & 0.018 & 0.075 & 1.005 & 0.086 & 2.104 & 14.83 \\
\hline
\end{tabular}

*Means sharing the same letter(s) in a column do not differ significantly at $\mathrm{p}<0.05$ according to Duncan's Multiple Range Test.

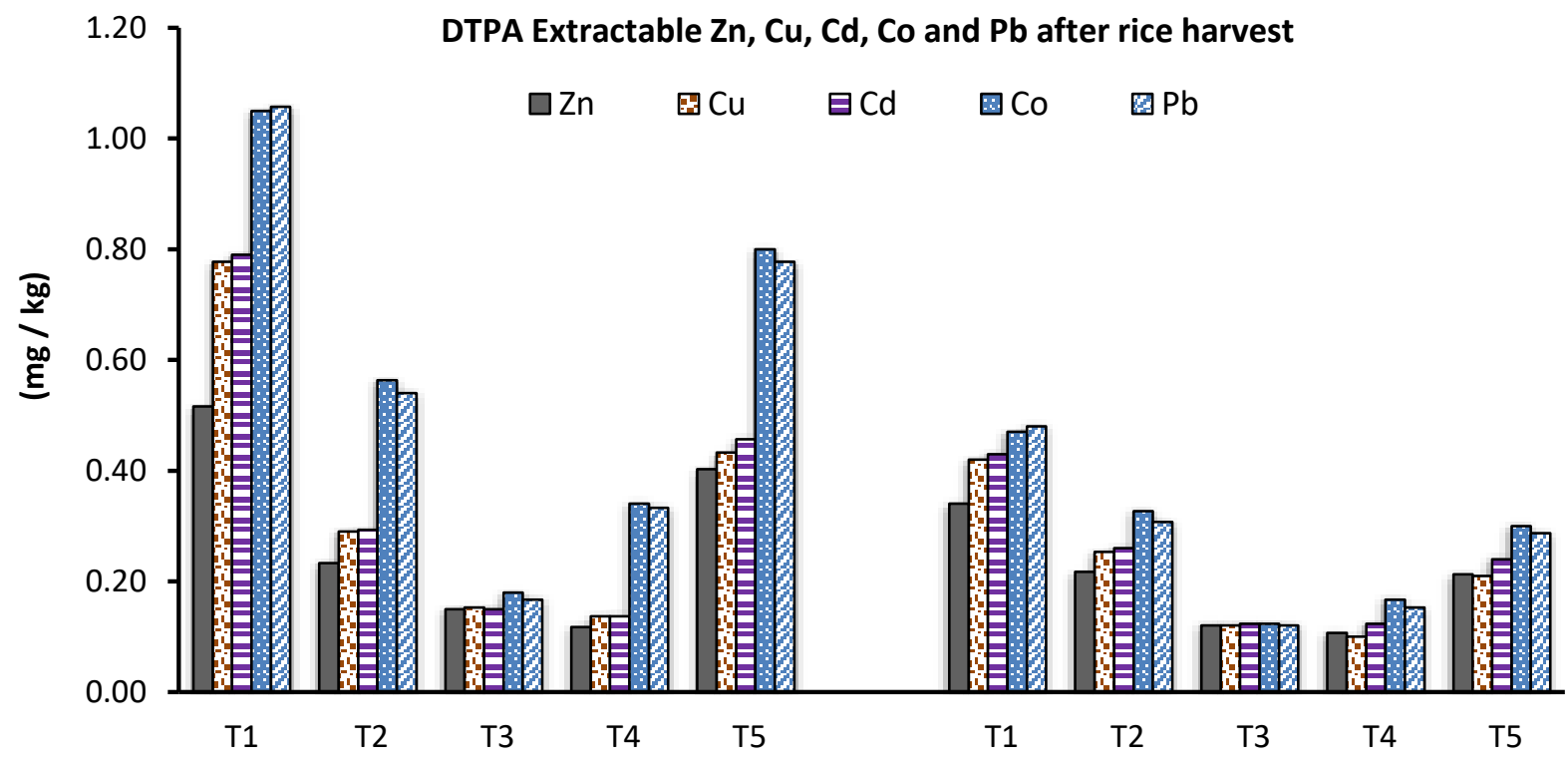

Figure 1. Soil analysis's after rice harvest at Kot Murad for DTPA Extractable ( $\mathrm{Zn}, \mathrm{Cu}, \mathrm{Cd}$. Co, Pb) at 0-15 cm and $15-30 \mathrm{~cm}$. $T_{1}$ - Control, $T_{2}$ - Recommended sole use of chemical fertilizers, $T_{3}$-Site specific use of chemical fertilizers, $\mathrm{T}_{4}$ - Integrated use of chemical fertilizers with MSWC in 80:20 ratio, $\mathrm{T}_{5}$-Site specific integrated use of chemical fertilizer with MSWC in 80:20 ratio.LSD for DTPA Extractable $\mathrm{Zn}, \mathrm{Cu}, \mathrm{Cd}$. Co, Pb for 0-15cm: 0.194, 0.130, 0.042, 0.089, 0.167.LSD for DTPA Extractable $\mathrm{Zn}, \mathrm{Cu}, \mathrm{Cd}$. Co, $\mathrm{Pb}$ for 15-30 cm: 0.074, 0.078, 0.022, 0.019, 0.049

The results regarding post-harvest soil analysis of rice and wheat (Table 4, 5 and Fig. 1,2) clearly demonstrated that salinity/sodicity of the soil were decreased initial values and decrease was higher in upper soil depth $(0-15 \mathrm{~cm})$. Slight improvement in organic matter, available $\mathrm{P}$, extractable $\mathrm{K}$ contents was observed. Maximum improvement in organic matter, available $\mathrm{P}$, extractable $\mathrm{K}$ contents was observed in integrated use of chemical fertilizers with MSWC in 80:20 ratio i.e. $0.620 \%, 13.27$ and $148.81 \mathrm{mg} \mathrm{kg}^{-1}$ and with site specific integrated use of chemical fertilizer with MSWC in i.e. $0.610 \%, 12.73$ and $148.25 \mathrm{mg} \mathrm{kg}^{-1}$.

Application of MSWC accumulated $\mathrm{Zn}, \mathrm{Cu}, \mathrm{Cd}$, Co and $\mathrm{Pb}$ especially in integrated use of chemical fertilizers with MSWC in 80:20 ratio $\left(T_{4}\right)$ and site specific integrated use of chemical fertilizer with MSWC in $\left(T_{5}\right)$ than the rest of treatments. Improvement in organic matter, available $\mathrm{P}$ and 


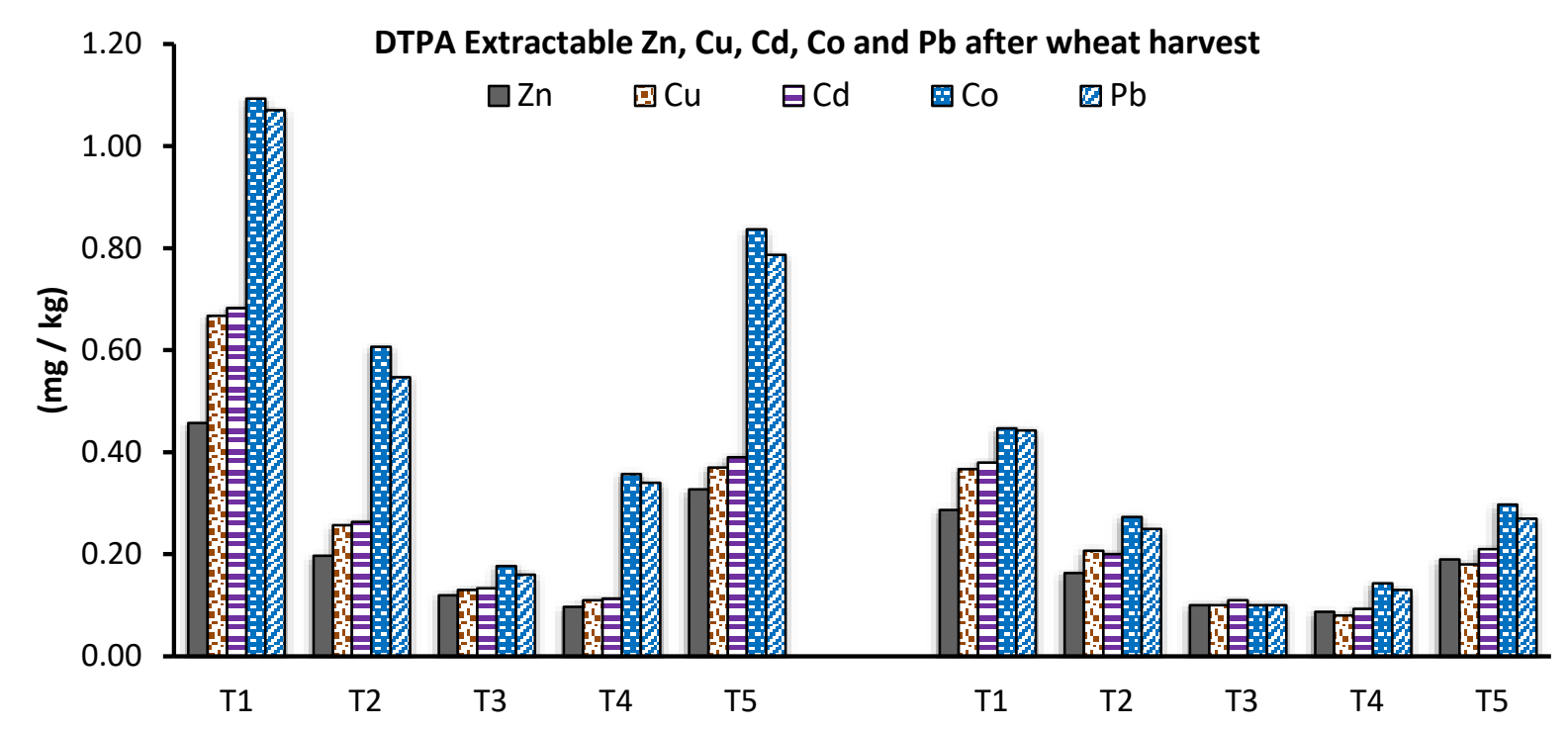

Figure 2. Soil analysis after wheat harvest at Kot Murad for DTPA Extractable ( $\mathrm{Zn}, \mathrm{Cu}, \mathrm{Cd}$. Co, Pb) at 0-15 cm and $15-30 \mathrm{~cm}$. $T_{1}$ - Control, $T_{2}$ - Recommended sole use of chemical fertilizers, $T_{3}$-Site specific use of chemical fertilizers, T4- Integrated use of chemical fertilizers with MSWC in 80:20 ratio, T5-Site specific integrated use of chemical fertilizer with MSWC in 80:20 ratio.LSD for DTPA Extractable $\mathrm{Zn}, \mathrm{Cu}, \mathrm{Cd}$. Co, $\mathrm{Pb}$ for 0-15cm: 0.165, 0.1026, 0.0492, 0.075, 0.114.LSD for DTPA Extractable Zn, Cu, Cd. Co, Pb for 15-30 cm: 0.074, 0.045, 0.011, 0.023, 0.019

extractable $\mathrm{K}$ was more in upper soil depth than lower soil depth especially in integrated use of chemical fertilizers with MSWC in 80:20 ratio $\left(\mathrm{T}_{4}\right)$ and site specific integrated use of chemical fertilizer with MSWC in ( $\left.\mathrm{T}_{5}\right)$ (Hussain et al., 2001; Qazi et al., 2009).

After rice harvest, increase in organic matter content was observed i.e. $0.277 \%$ to $0.620 \%$ with $\mathrm{T}_{4}$ and 0.610 with $\mathrm{T}_{5}$. Increase in available $\mathrm{P}$ and extractable $\mathrm{K}$ was observed compared to control and highest increase was observed i.e. 13.27 and $148.81 \mathrm{mg} \mathrm{kg}^{-1}$ with $\mathrm{T}_{4}$ and 12.73 and 148.25 with $\mathrm{T}_{5}$ compared to control i.e. 5.11 and $87.26 \mathrm{mg} \mathrm{kg}^{-1}$, respectively. After rice harvest, the highest decrease in $\mathrm{EC}_{\mathrm{e}}$ and SAR was observed in upper soil depth with sitespecific integrated use of chemical fertilizers with MSWC in 80:20 ratio $\left(\mathrm{T}_{5}\right)$ where values of EC and SAR were recorded as 3.15 and $21.71\left(\mathrm{dS} \mathrm{m}^{-1}\right.$ and $24.36\left(\mathrm{mmol} \mathrm{L}^{-1}\right)^{1 / 2}$, respectively. Integrated use of chemical fertilizers with MSWC in 80:20 ratio $\left(\mathrm{T}_{4}\right)$ revealed these parameters as 3.19 and $21.81\left(\mathrm{dS} \mathrm{m}^{-1}\right.$ and $24.36\left(\mathrm{mmol} \mathrm{L}^{-1}\right)^{1 / 2}$ as compared to control i.e. 4.13 and $24.36\left(\mathrm{dS} \mathrm{m}^{-1}\right.$ and $24.36\left(\mathrm{mmol} \mathrm{L}^{-1}\right)^{1 / 2}$, respectively.

After wheat harvest, increase in organic matter content was observed from 0.243 to $0.657 \%$ with integrated use of chemical fertilizers with MSWC in 80:20 ratio and 0.633 with site specific integrated use of chemical fertilizer with MSWC. Increase in available $\mathrm{P}$ and extractable $\mathrm{K}$ was observed compared to control and highest increase was observed i.e. 14.29 and $152.16 \mathrm{mg} \mathrm{kg}^{-1}$ with $\mathrm{T}_{4}$ and 13.13 and 152.52 with $\mathrm{T}_{5}$ compared to control i.e. 4.13 and $81.87 \mathrm{mg} \mathrm{kg}^{-1}$, respectively. After wheat harvest, the $\mathrm{EC}_{\mathrm{e}}$ and $\mathrm{SAR}$ were decreased and highest decrease in $\mathrm{EC}_{\mathrm{e}}$ and $\mathrm{SAR}$ was observed in upper soil depth with site-specific integrated use of chemical fertilizers with MSWC in 80:20 ratio i.e. $3.143 \mathrm{dS}$ $\mathrm{m}^{-1}$ and $21.35\left(\mathrm{mmol} \mathrm{L}^{-1}\right)^{1 / 2}$. Similar was the effect of integrated use of chemical fertilizers with MSWC in 80:20 ratio $\left(\mathrm{T}_{4}\right)$ i.e. 3.147 and 21.38 as compared to control i.e. $3.983\left(\mathrm{dS} \mathrm{m}^{-1}\right)$ and $22.62\left(\mathrm{mmol} \mathrm{L}^{-1}\right)^{1 / 2}$, respectively.

The growing of rice in flooded conditions might be due to the fact that soluble salts were leached down by improvement in infiltration rate and hydraulic conductivity resulting in decrease in soil $\mathrm{EC}_{\mathrm{e}}$ and SAR. Addition of organic content such as MSWC improved the granulation and aggregate stability might be the reason of reduction in $\mathrm{EC}_{\mathrm{e}}$ and $\mathrm{SAR}$ (Hussain et al., 2001; Qadir et al., 2001). Improvement in organic matter of soil with MSWC application was also in accordance with the findings of Hussain et al. (2001) and Qazi et al. (2009).

Application of organic content to salt affected soil improved the granulation, aggregate stability, soil health and promoted crop growth. Salt-affected soils characterized with disturbed soil structure and with low organic content enhanced the damage to crop growth (Blum et al., 2004; Van-Camp et al., 2004; Chitravadivu et al., 2009; Laland Follett, 2009). Application of MSWC to agriculture fields not only protect the environment due to their incineration and provide an economical method of dumping wastes but also improved the organic matter in soils that act as binding force to the dispersed conditions (Parnaudeau et al., 2004; Van-Camp et 
al., 2004; Gigliotti et al., 2005; Spargo et al., 2006). Application of MSWC also adds / conserves nutrients in soil and thus compensates the mineral fertilizers, improves the soil physical conditions (Bellamy et al., 1995; Tejada et al., 2001; Zhang et al., 2006; Weber et al., 2007).

Application of MSWC promotes soil available $\mathrm{P}$ and extractable $\mathrm{K}$ as reported in results i.e. in treatments sitespecific integrated use of chemical fertilizer with MSWC in $80: 20$ ratio and integrated use of chemical fertilizers with MSWC in 80:20 ratio. Improvement in available $P$ and extractable $\mathrm{K}$ with site-specific application of nutrient and integrated use of chemical fertilizers with MSWC was verified from the findings of many researchers (Warman et al.,2004; Zhang et al., 2006; Qazi et al., 2009). Site-specific application of $\mathrm{P}$ than conventional use is considered better approach by saving $\mathrm{P}$ and avoiding the losses (McLean et al., 1982; Glendinning, 1990; Juang et al., 2002).

Application of MSWC to agriculture fields besides its benefits of environmental safety, adding organic matter in soil may also cause severe threat by adding huge amount of heavy metals in soil (Zhang et al., 2006). Detailed soil analysis of fields and MSWC should be carried out to assess the extent of heavy metals for permissible limits of heavy metals (Weber et al., 2007). Minor increase in DTPA extractable $\mathrm{Zn}, \mathrm{Cu}, \mathrm{Co}$, $\mathrm{Cd}$ and $\mathrm{Pb}$ was observed in integrated use of chemical fertilizers with MSWC in 80:20 ratio and site specific integrated with MSWC in 80:20 ratio and other treatments. DTPA extractable $\mathrm{Zn}, \mathrm{Cd}, \mathrm{Cr}, \mathrm{Pb}$ and $\mathrm{Ni}$ were also enhanced with MSWC application (Qazi et al., 2009). It was reported that $\mathrm{Zn}, \mathrm{Ni}, \mathrm{Cd}, \mathrm{Cr}$ and $\mathrm{Pb}$ concentration was improved in soil with MSWC application (Hernando et al., 1989; Pinamonthi et al., 1999; Hargreaves et al., 2008).

Conclusion: Studies concluded that MSWC application with mineral fertilizer and site-specific application of $\mathrm{P}$ is an economical approach and results in crop growth promotion. Site-specific use of chemical fertilizers with MSWC and integrated use of chemical fertilizers with MSWC in 80:20 ratio increased the paddy/grain yield and fertility status of the soil. However, there was a slight increase in the heavy metal concentrations in soil in the treatments where MSWC was applied.

Acknowledgements: The authors gratefully acknowledge the Endowment Fund of University of Agriculture Faisalabad for financial support for this research.

\section{REFERENCES}

Alidadi, H., A.R. Parvaresh, M.R. Shahmansouri and H. Pourmoghadas. 2008. Evaluation of the biosolids compost maturity in south Isfahan wastewater treatment plant. Iran. J. Environ. Health Sci. Eng. 5:137-140.

Arain, M.A., M. Ahmad and M.A. Khan. 2000. Some physic o-chemical characteristics of soil in sugarcane cultivated areas of Nawabshah, Sindh, Pakistan. Pak. J. Bot. 32:93100.

Bellamy, K.L., C. Chong and R.A. Clin. 1995. Paper sludge utilization in agriculture and container nursery culture. J. Environ. Qual. 24:1074-1082.

Blake, G.R. and K.H. Hartge. 1986. Bulk and particle density, pp.363-382. In: A. Klute (ed.), Methods of Soil Analysis, Part 1. Agron. 9, SSSA, Madison, WI, USA.

Blum, W.E.H., J. Busing and L. Montanarella. 2004. Research needs in support of the European thematic strategy for soil protection. Trac-Trends Anal. Chem. 23:680-685.

Bouyoucos, G.J. 1962. Hydrometer method improved for making particle size analyses of soils. Agron. J. 54:464465.

Brady, N.C. and R.R. Weil. 2005. The Nature and Properties of Soils, $13^{\text {th }}$ Ed. Macmillan Publishing Company, New York; pp.279- 313.

Chinnusamy, V., A. Jagendorf and J.K. Zhu. 2005. Understanding and improving salt tolerance in plants. Crop Sci. 45:437-448.

Chitravadivu, C., V. Balakrishnan, J. Manikandan, T. Elavazhagan and S. Jayakumar. 2009. Application of food waste compost on soil microbial population in groundnut cultivated soil. Middle East J. Scient. Res. 4:90-93.

Chun, S., H. Rai, M. Nishiyama and S. Matsumoto. 2007. Using organic matter with chemical amendments to improve calcareous sodic soil. Comm. Soil Sci. Plant Anal. 38:205-216.

Dibb, D.W., P.E. Flexen and L.S. Murphy. 1990. Balanced fertilization with particular reference to phosphates. Fert. Res. 26:29-52.

Duncan, D.B. 1955. Multiple Range and Multiple F-Test. Biometrics 11:1-42.

Ghafoor, A., A. Rauf and W. Muzaffar. 1995. Irrigation with Madhuanadrain water: Impact on soils and vegetables (spinach and cauliflower) at Faisalabad. J. Drain. Recla. 7:7-12.

Ghafoor, A., G. Murtaza, A.A. Maann, M. Qadir and B. Ahmad. 2011. Treatments and economic aspects of growing rice and wheat crops during reclamation of tile drained saline-sodic soils using brackish waters. Irrigation and Drainage 60:418-426

Gigliotti, G., A. Onofri, E. Pannacci, D. Businelli and M. Trevisan. 2005. Influence of dissolved organic matter from waste material on the phytotoxicity and environmental fate of triflusulfuron methyl. Environ. Sci. Technol. 39:7446-7451.

Hanay, A.F. Büyüksönmez, F.M. Kiziloglu, M.Y. Canbolat. 2004. Reclamation of saline-sodic soils with gypsum and MSW compost. Compost Sci. Utilization 12:175-179. 
Hargreaves, J.C., M.S. Adl and P.R. Warman. 2008. A review of the use of composted municipal solid waste in agriculture. Agric. Ecosys. Environ. 123:1-14.

Hasegawa, P.M., R.A. Bressan, J.K. Zhu and H.J. Bohnert. 2000. Plant cellular and molecular response to high salinity. Ann. Rev. Plant Physiol. Plant Mol. Biol. 51:463-499.

Hernando, S., M. Lobo and A. Polo. 1989. Effect of the application of municipal refuse compost on the physical and chemical properties of soil. Sci. Total Environ. 81/82:589-596.

Hussain, N., G. Hassan, M. Arshadullah and F. Mujeeb. 2001. Evaluation of amendments for the improvement of physical properties of sodic soil. Int. J. Agric. Biol. 3:319-322.

Juang, K.W., D.C. Liou and D.Y. Lee. 2002. Site-specific phosphorus application based on the kriging fertilizerphosphorus availability index of soils. J. Environ. Qual. 31:1248-1255.

Lal, R. and R.F. Follett (Eds.) 2009. Soil carbon Sequestration and the Greenhouse Effect. Soil Sci. Soc. Am. Special Publ. 57, Second Edition, Madison WI, 410 pp.

Lindsay, W.L. and W.A. Norvell. 1978. Development of a DTPA soil test for zinc, iron, manganese and copper. Soil Sci. Soc. Am. J. 42:421- 428.

Madejon, E., R. Lopez, J.M. Murillo and F. Cabrera. 2001. Agricultural use of three (sugar beet) vinasse composts: Effect on crops and chemical properties of Cambisol soil in the Gauadalquivir river valley (SW Spain). Agric. Ecosyst. Environ. 84:55-65.

Mansour, M.M.F. and K.H.A Salama. 2000. Cellular basis of salinity tolerance in plants. Environ. Exp. Bot. 52:113122.

McLean, E.O., T.O. Oloya and S. Mostaghimi. 1982. Improved corrective fertilizer recommendations based on a two-step alternative usage of soil tests: I. Recovery of soil-equilibrated phosphorus. Soil Sci. Soc. Am. J. 46:1193-1197.

Melero, S., E. Madejón, J.F. Herencial and J.C. Ruiz.2007. Biochemical properties of two different textured soils (loam and clay) after the addition of two different composts during conversion to organic farming. Span. J. Agric. Res. 5:593-604.

Munns, R. and M. Tester. 2008. Mechanisms of salinity tolerance. Ann. Rev. Plant Biol. 59:651-681.

Parnaudeau, V., B. Nicolardot and J. Pages. 2004. Relevance of organic matter fractions as predictors of waste sludge mineralization in soil. J. Environ. Qual. 33:1885-1894.

Pinamonthi, F., G. Niciloni, A. Dalpiaz, G. Stringari and G. Gorzi. 1999. Compost use in viticulture: effects on heavy metal levels in soils and plants. Commun. Soil Sci. Plan. 30:1531-1549.
Qadir, M., A. Ghafoor and G. Murtaza. 2001. Use of salinesodic waters through phytoremediation of calcareous saline-sodic soils. Agric. Water Manage. 50:197-210.

Qadir, M., J.D. Oster, S. Schubert, A.D. Noble and K.L. Sahrawat. 2007. Phytoremediation of sodic and salinesodic soils. Adv. Agron. 96:197-247.

Qazi, M.A., M. Akram, N. Ahmad, J.F. Artiola and M. Tuller. 2009. Economical and environmental implications of solid waste compost applications to agricultural fields in Punjab, Pakistan. Waste Manage. 29:2437-2445.

Rajendran, K., M. Tester and S.J. Roy. 2009. Quantifying the three main components of salinity tolerance in cereals. Plant Cell Environ. 32:237-249.

Schachtman, D.P., R.J. Reid and S.M. Ayling. 1998. Phosphorus uptake by plants: From soil to cell. Plant Physiol. 116:447-453.

Sharma, B.R. and P.S. Minhas. 2005. Strategies for managing saline/alkali waters for sustainable agricultural production in South Asia. Agric. Water Manage. 78:136151.

Sherani, J., M.S. Jillani and T. Ahmad. 2017. Ber (Zizyphus mauritiana L.) production and quality as influenced by different salinity levels in water. Pak. J. Agri. Sci. 54:645-652.

Spargo, J.T, G.K. Evanylo and M.M. Alley. 2006. Repeated compost Application effects on phosphorus runoff in the Virginia piedmont. J. Environ. Qual. 35:2342-2351.

Steel, R.G.D., J.H. Torrie and D.A. Dickey. 1997. Principles and Procedures of Statistics: A biometrical approach. McGraw Hill Co. Inc. New York.

Tandon, H.L.S. 2005. Methods of analysis of soils, plants, waters, fertilizers and organic manures. Fertilizer development and consultation organization 204-204A Bhanot, 1-2 Pamposh Enclave New Delhi-110048, India; p. 203.

Tejada, M., C. Garcia, J.L. Gonzalez and M.T. Hernandez. 2006. Use of organic amendment as a strategy for saline soil remediation: Influence on the physical, chemical and biological properties of soil. Soil Biol. Biochem. 38:1413-1421.

Tejada, M., M.M. Dobao, C. Benitez and J.L. Gonzalez. 2001. Study of composting of cotton residues. Biores. Technol. 79:199-202.

Tzortzakis, N., S. Gouma, C. Paterakis and T. Manios. 2012. Deployment of municipal solid wastes as a substitute growing medium component in marigold and basil seedlings production. Scientific World J. Vol. 2012, Article ID: 973193,8 pages.

U.S. EPA. 1995. Process Design Manual: Land application of sewage sludge and domestic septage Office of Research and development. EPA / 625 / R-95 /001. Washington, DC. p.13. 
U.S. Salinity Lab. Staff. 1954. Diagnosis and Improvement of Saline and Alkali Soils. USDA Handbook No. 60, Washington, DC, USA.

Van-Camp, L., B. Bujarrabal, A-R. Gentile, R.J.A. Jones, L. Montanarella, C. Olazabal and S.K. Selvaradjou. 2004. Reports of the Technical Working Groups Established under the Thematic Strategy for Soil Protection, EUR $21319 \mathrm{EN} / 3$, Office for Official Publications of the European Communities, Luxembourg; p.872.

Watanabe, F.S. and S.R. Olsen. 1965. Test of an Ascorbic acid method for determining phosphorus in water and $\mathrm{NaHCO}_{3}$ Extracts from soil. Soil Sci. Soc. Am. Proc. 29:677- 678 .

Weber, J., A. Karczewska, J. Drozd, M. Licznar, S. Licznar, E. Jamroz and A. Kocowicz. 2007. Agricultural and ecological aspects of a sandy soil as affected by the application of municipal solid waste composts. Soil Biol. Biochem. 39:1294-1302.

Wong, V.N.L. R.C. Dalal and R.S.B. Greene. 2009. Carbon dynamics of sodic and saline soil following gypsum and organic material additions: A laboratory incubation. Applied Soil Eco. 41:29-40.

Yaghmaeian, K., M. Malakootian and M. Noorisepehr. 2005. Comparison between windrow and pit composting of poultry wastes, leaves and garbage of municipal solid waste in Damghan, Iran. J. Env. Health Sci. Eng. 2:2227.

Zhang, M., D. Heaney, B. Henriquez, E. Solberg and E. Bittner. 2006. A four-year study on influence of biosolids/MSW compost application in less productive soils in Alberta: Nutrient dynamics. Compost Sci. Util. 14:68-80. 